\title{
Virtue and Civic Values in Early Modern Jesuit Education
}

\author{
Jaska Kainulainen \\ University of Helsinki \\ Jaska.kainulainen@helsinki.fi
}

\begin{abstract}
The article suggests that by offering education in the studia humanitatis the Jesuits made an important contribution to early modern political culture. The Jesuit education facilitated the establishment of political rule or administration of civic affairs in harmony with Christian virtues, and produced generations of citizens who, while studying under the Jesuits, learned to identify piety with civic values. In educating such citizens the Jesuit pedagogues relied heavily on classical rhetoric as formulated by Cicero (106-43 вС), Quintilian (35-100), and Aristotle (384-322 BC). The article depicts the Jesuits as civic educators and active members of respublica christiana. In so doing, the article emphasizes the importance of Jesuit education to early modern political life.
\end{abstract}

\section{Keywords}

Jesuit education - civic values - virtue - rhetoric - Cicero - Renaissance humanism

This article takes its cue from the observation that Jesuit education was based on the example laid down by the humanist educators of the Renaissance. ${ }^{1}$ The

1 For this argument, see John W. O'Malley, The First Jesuits (Cambridge, MA: Harvard University Press, 1993), 13-14, 208-12; Paul Grendler, Schooling in Renaissance Italy: Literacy and Learning, 1300-16oo (Baltimore: Johns Hopkins University Press, 1989), 376-78; Marc Fumaroli, L'Âge de l'éloquence: Rhétorique et res literaria de la Renaissance au seuil de l'époque classique (Geneva: Droz, 2009), 175-76; Robert A. Maryks, Saint Cicero and the Jesuits: The Influence of the Liberal Arts on the Adoption of Moral Probabilism (Farnham: Ashgate, 2008), 77.

(C) JASKA KAINULAINEN, 2018 | DOI:10.1163/22141332-00504003

This is an open access article distributed under the terms of the prevailing CC-BY-NC license at the time of publication. 
Jesuit schools' debt to Renaissance humanism is most evident in their curricula and syllabi, which, to a large extent, replicated the core readings used in humanist schools. I suggest that the emphasis the Jesuits laid on the studia humanitatis - and on the teaching of rhetoric in particular-furnished the Jesuit education with an intrinsically civic quality and brought about significant political implications. In what follows, I seek to demonstrate that Jesuit colleges contributed to the establishment and administration of respublica christiana (political rule or administration of civic affairs in harmony with Christian virtues) by educating generations of Christian citizens who, while studying under the Jesuits, learned to identify piety with civic values. In line with this argument, the article presents the Jesuits as civic educators and active members of respublica christiana. By offering students instruction in the studia humanitatis, a daily Mass, and frequent confession and Communion, the Jesuit ministry of secondary education aimed to produce Christian citizens capable of administering civic affairs for the greater glory of God. ${ }^{2}$ In so doing, early modern Jesuit education laid solid foundations for political governance, which was marked by both civic and pious concerns.

The principal goal of the Society of Jesus was to "save souls," to help people live according to such moral standards, which were deemed indispensable for salvation. This objective was chiefly achieved through preaching and edifying the youth and the illiterate. What had initially been rudimentary instruction in Christian doctrine, quickly developed into the most organized and widespread network of secondary education in the early modern world. Despite the religious nature of the Society of Jesus, only a small percentage of the students who attended Jesuit schools continued to study theology or philosophy at university level. Most students sought out employment after having completed the lower classes that consisted of the studia humanitatis (that is, Latin and Greek grammar, poetry, history, moral philosophy and rhetoric). The Jesuits provided a large number of people with literacy in Latin and Greek, with the knowledge of history and moral philosophy, and with the ability to speak and argue persuasively in public. In other words, the rapidly expanding network of Jesuit schools educated citizens who took active roles in their local communities. Guided by Christian doctrine, these magistrates, secretaries, and advisers maintained respublica christiana through their habitual application of civic values such as rhetorical competence and dedication to vita activa (active life). The Jesuit ministry of education was inspired by the desire to advance

2 The Constitutions of the Society of Jesus, trans. George E. Ganss, S.J. (St. Louis, Mo: Institute of Jesuit Sources, 1970), 184: "confession and Communion, which they will frequent every eight days, and Mass which they will hear every day." 
Christian virtues in the society. At the same time, following the humanist appreciation of pagan writers such as Cicero, the Jesuit pedagogues promoted and relied on human agency in their enterprise.

Much of my argument about the civic quality of the Jesuit education is based on the view that sixteenth-century educators regarded classical rhetoric as a political science. For Cicero, rhetoric constituted the essence of statesmanship, and this interpretation of ars rhetorica was revived by Renaissance humanists such as Leonardo Bruni (1370-1444). It is significant that the Jesuits did not limit their teaching to vernacular grammar or to providing rudimentary instruction in the catechism (which is what they first did), but quickly established colleges, which focused on classical studies. Why would a religious organization choose to teach Homer, Isocrates (436-336 вC), Cicero, Virgil ( $70-19$ вC), and Horace (65-8 вС), instead of the catechism? Why would they choose to teach classical rhetoric instead of the basic tenets of Christianity? Why is it that Cicero features in the Jesuit manuals of lower education more frequently than the church fathers? All this suggests that the Jesuits embarked on an ambitious enterprise, which aimed to combine religious and civic aspirations in order to produce saintly citizens who were informed of and guided by both Christian and civic virtues. By so doing, the Jesuits were motivated to impart key civic skills to the "rich and poor alike, without distinction," as their leader Ignatius of Loyola $(c .1491-1556)$ put it. $^{3}$

\section{Christian Virtues and Civic Values}

Rather than limiting their edifying work to the indoctrination of exclusively Christian virtues such as humility, chastity, and obedience the Jesuits also inculcated their students with civic values. These included the appreciation of vita activa (active engagement in civic affairs), advancement of the common good and justice, and the possession of good communication skills. The students were repeatedly exposed to the civic ethos of Cicero's writings, parts of which they were expected to learn by heart. Apart from the more audacious writers - such as Terence (d.159 BC) and Martial (40-104) - the Jesuits were remarkably unruffled by the pagan aspects of the classical literature that they taught. At the same time, they did not hesitate to express their admiration for the virtuous characteristics of writers such as Cicero. For example, when the English Jesuit Thomas Fitzherbert (1552-1640) attacked what he considered Machiavelli's (1469-1527) "impious" doctrine that recommended deceit, he

3 I quote from O'Malley, First Jesuits, 67. 
resorted to Cicero's authority, and asserted that according to Cicero "fides, which we may call fidelity," is "the foundation of justice."

A vast proportion of the students who spent up to five years to complete the lower, pre-university curriculum of Jesuit education chose not to pursue an ecclesiastical career. ${ }^{5}$ Finding employment as magistrates, clerks, and secretaries, they contributed to the administration of local governing bodies and to the setting up of civic rituals and ceremonies. At the same time, a school day in a Jesuit college was organized around religious rituals. The early modern Jesuit education provided students with administrative skills which were based on a moral and civic edification that was modelled after the educational agenda of the Renaissance humanists.

The Jesuit educators shared the humanists' concern for the advancement of the common good. From the beginning, self-abnegation for the benefit of others featured as one of the key virtues championed by the Jesuit order. An early constitutional text De abdicatione bonorum in favorem Societatis (1548) exhorts the members of the Society of Jesus to "abnegate" all self-interests for the sake of "the greater and more universal good of the Society," which was established "for the greater glory of God and for the greater common good." 6 The concern for the common good was ratified in the papal bull Exposcit debitum (1550), one of the key constitutional texts of the Jesuit order, which asserts that the Society of Jesus performed works of charity "for the glory of God and the common good."7 Individual Jesuits reinforced this ethos in their correspondence, as we can judge from Alfonso Salmerón's (1515-85) assurance that he was "not looking at my own particular" interest, but at the "greater universal good of the Society" and "the common edification and consolation." ${ }^{8}$ These few examples

4 Thomas Fitzherbert, The First Part of a Treatise Concerning Policy, and Religion (Douai: Laurence Kellam, 1606), 342.

5 This is suggested by the interviews of those who wanted to enter the English College in Rome, published in A. J. P. Kelly, ed., The Responsa Scholarum of the English College, Rome: 1622-1685 (London: The Catholic Record Society, 1963).

6 Arthurus Codina, ed., Sancti Ignatii de Loyola Constitutiones Societatis Jesu, vol. 1: Monumenta Constitutionum praevia (Rome: Borgo S. Spirito 1934), 247: "abnegatión de todo amor proprio [...] sino antes el bien mayor y más universal de la Compañia (siendo ella ordenata a mayor gloria divina y a deseando mayor bien universal."

7 Arthurus Codina, Sancti Ignatii de Loyola Constitutiones, 376: "ac reliqua charitatis opera [...] ad Dei gloriam et commune bonum."

8 Fridericus Cervós, ed., Epistolae P. Alphonsi Salmeronis Societatis Jesu ex autographis vel originalibus exemplis potissimum depromptae a Patribus ejusdem Societatis nunc primum editae, vol. 2: 1565-1585 (Madrid: López del Horno, 1907), 26: "no mirando a cosa mía particular [...] sino el mayor bien universal de la Compañia [...] y edificación commún y consolación.” 
indicate the Jesuits' tendency to unify the religious with the civic. While the advancement of the common good is explicitly civic in nature, self-abnegation bears on Christian aspiration for purity and the freedom from sin.

Supervising the rapid growth of the Society's educational network Loyola sent the Jesuit provincial of Spain Antonio Araoz (1516-73) instructions about how to establish and organize a college. The letter-written by the Society's secretary Juan Alfonso de Polanco (1517-76) under Loyola's directiontestifies to the view that Jesuit education cannot be separated from notions of virtue and civic life. According to the letter, teachers were guided to supervise that the students exercised "disputations and compositions," and "always spoke Latin in such a manner that they made good progress both in letters and virtues." ${ }^{9}$ Furthermore, according to Loyola and Polanco the fact that Jesuit schools instructed students in Christian doctrine and the humanities was beneficial to teachers, students, parents, and the society alike. More specifically, they asserted that Jesuit schools were beneficial to the Jesuit teachers themselves, because they could "learn a lot from teaching others"; to the students, because they received free education in letters and Christian doctrine, making progress in "purity of conscience" and in "all virtue"; to the parents who did not have to pay for the education of their children, nor did they have to worry about finding a teacher they could trust; to the society, because the presence of the Jesuits provided the community with people who were able to "inspire and help" others to understand and perform "good works," and also, because in the students the society had individuals who could "preach," "govern the land and administer justice." The "good education in life and doctrine" that these youths received from the Jesuits, would "greatly benefit others" and would continue to increase the beneficial effects every day. ${ }^{10}$

The Jesuit Constitutions exhorted the teachers to guide the students towards "compliance and love of God and virtue," and to ensure that all their

Vincentius Agustí and Marianus Lecina, eds., Sancti Ignatii de Loyola Societatis Jesu fundatoris epistolae et instructiones, 12 vols. (Madrid: López del Horno, 1903-11), 4:6: "haziéndoles exercitarse en disputar y componer y siempre hablar latin, en manera que se aprovechan mucho en las letras juntamente con las virtudes."

$10 \quad$ Ibid., 7-9: "los que leyen se ayudan y aprenden mucho enseñando á los otros [...] los pobres [...] aquí hallan gratis lo que costa mucha apenas podrían aver para salir las letras [...] aprendiendo la doctrina christiana [...]. En la puridad de la conscientia se aprovechan, y consiguentemente en toda virtud [...]. Tienen en los nuestros los de la tierra quién los anime y ayude para las obras pias [...] studiantes [...] quién para predicar y tener cura de las animas, quién para el govierno de la tierra y administratión de la justitía $[\ldots]$ y finalmente $[\ldots]$ la buena institutión en vida y doctrina destos aprovechará á otros muchos, estendiéndose cada día más el fructo." 
"studies were directed towards this end."11 While love of God constituted an abstract, metaphysical foundation, which both motivated and justified the undertakings of the Society of Jesus, the aspiration to be virtuous endowed the Jesuits with concrete guidelines how to function as members of the wider society. Christian virtues consisted of notions such as charity, humility, chastity, poverty, and obedience. But, what emerges from the vast amount of Jesuit writings on education is the assertion that education should advance the common good. In line with this observation, the educational writings of the Jesuit order suggest that the Jesuit notion of virtue was marked by a constant call for vita activa. At the same time, participation in civic life necessitated certain linguistic and rhetorical skills, which were provided by the studia humanitatis. The teaching of grammar, poetry, history, moral philosophy, and rhetoric thus became a cornerstone of the Jesuit implementation of virtues, which were at once informed by the Christian principle of charity and humanist notion of vita civile (civic life).

The amalgamation of Christian and humanist principles in Jesuit pedagogy is reiterated in a host of documents that deal with education. For example, the guidelines written for the rector of the Jesuit college in Rome in 1551 state that the first duty of the rector is to ensure that the students "conserve and strengthen" their Christian "spirit and virtue," while the second duty is to make sure that the students "make progress in letters." ${ }^{\text {"2 }}$ Another similar document, Regulae et monita scholarum S.I. in Italia $\left(1555^{-56}\right)$, asserts that since the aim of the Society of Jesus was "the greater glory of God" and "the well-being and edification of our neighbors," the students who attended Jesuit schools should bear these objectives in mind and "use all their industry to learn literature [buone lettere]," which will turn them into "tools" that will "glorify the holy name of God and serve the neighbors." ${ }^{13}$

11 Ladislaus Lukács, ed., Monumenta paedagogica Societatis Iesu, 7 vols. (Rome: Monumenta Historica Societatis Iesu, 1965-92), 1:311: "ad obsequium et amorem Dei ac virtutum [...] movendos, et ut omnia sua studia ad hunc finem referant."

12 Ibid., 1:66: "La prima è che li scholari si conservino et aggiutino nel spiritu et virtù christiane et relligiose. La seconda che faciano profetto nelle lettere."

13 Ibid., 1:345: "Essendo ch'l fine di nostra Compagnia in tutti gl'essercitii et ministerii suoi è il maggior honor di Dio N.S. et la salute et edificatione commune delli prossimi, quelli che sonno destinati al studio hanno d'haver l'occhio molto intento a questo fine, accioché voluntieri s'affatigano per imparare, et usino tutta la diligenza loro per acquistare buone lettere, donde poi con quelle siano instrumenti di glorificare il nome santo di Dio et di servire alli prossimi." 


\section{Language, Communication, and Human Agency}

In line with the Renaissance humanists, Jesuit pedagogues based their educational system on the assumption that language and communication skills mattered. While Greek — and occasionally Hebrew—were taught as well, the main focus was placed on Latin. Correct and eloquent Latin was studied under the auspices of Cicero, Sallust (86-35 вС), Virgil, Terence, and, at least in the beginning, Lorenzo Valla (1407-57) and Erasmus (1466-1536). Latin was a prerequisite for more advanced university studies, the language not only of theology, but of erudition and the sciences. At the same time, Latin provided the students with access to classical literature, both pagan and Christian. This was important, because fluency in Latin and knowledge of classical literature were considered necessary qualifications for those who wished to enter a Renaissance court or to pursue a career in the administration of a city-state, kingdom, or empire.

However, the pre-university level Jesuit education was not only concerned with classical languages. Latin may have been the language of the learned and as such sufficient for those whose principal social network was the republic of letters, but the Jesuits also engaged with those who possessed no formal education at all. Participating in social or civic affairs was a fundamental part of being a Jesuit. As testified by Polanco, Loyola informed his confrères in 1555 that regardless of their whereabouts they should always study the local vernacular, "Italian in Italy, French in France."14 In the same year, Loyola stipulated that the students of the German College in Rome should be taught Italian, and were expected to converse in Italian for two hours every day. ${ }^{15}$ Not surprisingly, Jesuit correspondence testifies to the polyglot capabilities of individual members of the order. For example, the French Pierre Favre (1506-46) wrote letters in Latin, Spanish, Italian, and French; Spanish Jesuits, including Loyola himself, Jerónimo Nadal (1507-80), Francisco de Borja (1510-72), Diego Laínez (151265), and Pedro de Ribadeneyra (1527-1611), wrote in Latin, Spanish, and Italian.

Although inseparable from pious notions and objectives, the pre-university level Jesuit education was not solely_or even primarily_concerned with the education of future priests. Its aim was to produce pious, Christian citizens, only some of whom would join the Jesuit order or otherwise pursue an ecclesiastical career. What the Jesuit schools aimed at was a well-rounded,

\footnotetext{
14 Ibid., 1:590: "ut in singulis provinciis nostri linguam illam addiscere curarent, quae in eadem provincia vernacula esset, ut in Italia italicam et (in) Gallia gallicum."

15 Ibid., 1:129: "perpetuo iubet latine loqui, exceptis duabus horis [...] in quibus horis non alio etiam illi quam italico idiomate utentur."
} 
comprehensive education. "Seriously taken studies," Nadal wrote in 1553, "demand, in a certain way, the entire man."16 This comprehensive understanding of education echoed the objectives of humanist schools, which in turn owed much to the Ciceronian view of the perfect orator as someone trained in many disciplines and fields of knowledge.

The aim to provide a well-rounded education was determined by the Jesuit order's principal objective to "save souls" or, to put it in more civic terms, to "help others" and to advance the common good. With this end in mind, it is hardly surprising that the pre-university level Jesuit education focused on imparting language and communication skills. These basic civic skills were also a necessary prerequisite for anyone wishing to join the Jesuit order: ideal candidates were expected to have certain natural inclination to learn and converse with others. The Society of Jesus should not seek to "incorporate everybody" as its members, Loyola wrote to Claude Le Jay $\left(1505^{-52}\right)$, but only those who were considered "useful to the end of helping one's neighbors." ${ }^{17}$ Loyola then moved on to specify the characteristics of such "useful" candidates. In the first place, they should either be learned or be capable of becoming so; secondly, they should be willing to "perfect themselves and help others"; thirdly, they should have eloquence, since "they will have to converse with others" somewhat frequently; furthermore, they should be honest "with regard to edifying others" and have enough "physical strength and health to endure" the work necessitated by the Society's agenda. ${ }^{18}$

The expectations imposed on Jesuit novices demonstrate that the Society of Jesus was centered on civic rather than monastic values. "We are not monks," Nadal repeatedly told his confrères. ${ }^{19}$ Many of the expectations directed to those who wished to join the Jesuits were also in harmony with the humanist culture of Renaissance Europe. Loyola's message - the exhortation to study, learn, and strive for the perfection of the self-echoed the humanists' insistence on the dignity of man. Broadly speaking, this was a view in opposition to

16 Ibid., 1:209-10: "los estudios tomados de veras, como la Compañía suele, piden, en cierto modo, el hombre entero."

17 Agustí and Lecina, Sancti Ignatii de Loyola Societatis Jesu fundatoris, 4:36: "non li abbraccia per tutti incorporarli nella medesima Compagnia, anzi solamente quelli che si reputano utili per il fine che si pretende del aiuto de li proximi."

18 Ibid., 4:37: "Primo, buona dottrina, o ingegno et memoria conveniente per impararla [...] 2., che habbino buona voluntà inclinata alla perfettione sua et aiuto de li proximi. 3., che habbino gratia alcuna di parlare, havendo ad conservar con altri assai, secondo l'istituto nostro. 4., l'apparentia honesta, quanto per edification' del proximo conviene. 5., che habbia sanità et forze corporali da poter sopportare le fatiche del nostro instituto." 
such sixteenth-century assertions of human depravity as John Calvin's (150964) theory of predestination and the widespread tendency to interpret human agency in line with the Augustinian view of postlapsarian and sinful man. In this broad sketch, the Jesuits sided with the Renaissance humanists and based their educational agenda on the assumption that man is capable of learning and cooperation. ${ }^{20}$

While the Jesuits' principal objective was to help others, they sought to achieve this through ministries such as preaching, confessions, and spiritual exercises. The first constitutional documents of the Society of Jesus-Formula Instituti (1539) and the bulls Regimini militantis ecclesiae (1540) and Exposcit debitum (1550) state that the Jesuits strive "for the progress of souls in Christian life" by the ministries of "word," "Spiritual Exercises," "charity," and "the education of children and unlettered persons in Christianity."21 The education mentioned in these documents is rudimentary in nature and refers to the teaching of catechism to children and the illiterate. This had very little to do with the education that the Jesuits became famous for. For the rest of his life, Loyola continued revising the Jesuit Constitutions, which were ratified in the first general congregation of the order in 1558. It was these revisions that allowed education to become a principal preoccupation of the Jesuits. ${ }^{22}$ Part four of the final version of the Jesuit Constitutions is dedicated to educational matters and much of the correspondence between Loyola and other leading Jesuits during the last few years of Loyola's life deals with issues related to the establishment and running of schools. While the Constitutions do not explicitly state that the teaching of academic subjects numbers among Jesuit ministries, this was made clear in the Jesuit Ratio studiorum (1599), which begins by referring to academic education as "one of the primary ministries of our Society."23

20 Whereas the Jesuits built a global network of schools, Augustinian thinkers such as Pierre Charron (1541-1603) and Paolo Sarpi $\left(155^{-1623)}\right.$ went as far as questioning the benefits of education (see, for example, Pierre Charron, Of Wisdom, trans. George Stanhope [London: R. Bonwick et al., 1707], 249-53; Paolo Sarpi, Pensieri naturali, metafisici e matematici, ed. Luisa Cozzi and Libero Sosio [Milan: Ricciardi, 1996], 593).

21 For the development of this point in different constitutional texts, see Maryks, Saint Cicero and the Jesuits, 16; John O'Malley, "Introduction: The Pastoral, Social, Ecclesiastical, Civic, and Cultural Mission of the Society of Jesus," in The Jesuits II: Cultures, Sciences, and the Arts, 1540-1773, ed. John O'Malley et al. (Toronto: University of Toronto Press, 2006), xxix-xxx.

22 O'Malley, First Jesuits, 6, 15, 200-1; Maryks, Saint Cicero and the Jesuits, 13, 83.

23 Ratio atque institutio studiorum Societatis Iesu (Antwerp: Apud Ioannem Meursium 1635), 5: "ex primarijs Societatis nostrae ministerijs unum sit." 
In contrast to medieval celebrations of contemptus mundi (contempt for the world), the Jesuits nurtured an attitude that was exceptionally responsive to the society outside their immediate religious context. This was partly because the Jesuits were not an isolated monastic fraternity, but, instead, a group of itinerant preachers, teachers, and confessors whose daily life was marked by encounters with people who were not members of their order. More to the point, the Jesuits' social or civic attitude was determined by the specific characteristics of their religious calling as formulated in their constitutional writings. At all times, a Jesuit was expected to be part of a wider society through the order's fundamental objective to help others. Besides running churches and schools, this overriding principle took individual Jesuits to hospitals, prisons, and the streets, where they sought to console and edify murderers, prostitutes, and the terminally ill. The Jesuits' agenda was an amalgamation of religious calling and civic activity, and, as John O'Malley has suggested, their driving force could be defined as "civic and culturally aware spirituality."24

The civic quality of Jesuit spirituality suggests that the Jesuit vision of respublica christiana was to a large extent fulfilled through human agency. Again, the Jesuits stood in opposition to those theological traditions, which, like Calvinism and Augustinianism, emphasized the polarity between human limitations and divine omnipotence. The Jesuits followed, by and large, the Aristotelian and Thomist interpretation of man as a "social and political animal." 25 Furthermore, their conception of man as a political agent was compatible with the humanist notion of human dignity. The civic spirituality of the Jesuits embodied a union between Thomist Christianity and civic humanism: the first provided the Jesuits with religious guidelines, while the latter inspired them in terms of societal engagement through the teaching of civic values and communication skills.

\section{The Jesuit Curriculum}

The purpose of the Jesuit ministry of education was to save souls, but it also provided students with skills and knowledge that the Renaissance humanists deemed necessary constituents of vita civile. To a large extent, the Jesuit teachers appropriated the curricula used at humanist schools and thus employed a host of pagan authors "for the progress of souls in Christian life and

\footnotetext{
24 O'Malley, "Introduction," xxxiv.

25 Thomas Aquinas, Political Writings, ed. Robert W. Dyson (Cambridge: Cambridge University Press, 2002), 6 n. 17: "naturale autem est homini ut sit animal sociale et politicum."
} 
doctrine." That the Jesuits taught Cicero and Sallust in a manner that advanced "Christian life," that is, in a manner that underlined such moral notions, which were compatible with Christian virtues, does not mean that the Jesuit teachers would have-even if they would have wanted to-purified or censored the essentially civic message promoted by these authors.

That the Jesuit secondary education drew heavily on Cicero is manifested in the Ratio studiorum, which declares that "style should be copied from Cicero" and that "all of Cicero's works are appropriate models of style." ${ }^{26}$ It would be mistaken, however, to consider Jesuit educational ideals exclusively receptive of Cicero's stylistic merits and dismissive of the contents of his writings. It is implausible that the Jesuits would have embraced and copied the humanist educators' curricula, which centered on language, communication, and rhetoric, without any awareness of the humanists'-and Cicero'sexpositions of the reasons why language and rhetoric were important to them. It is, in other words, implausible that the Jesuits would not have been aware of the Ciceronian and humanist notion of classical rhetoric as an indispensable constituent of citizenship and civic freedom. That the Jesuits were aware of the political implications of their humanist education - and fully aware of the political content of Cicero's writings-is demonstrated for example by Cipriano Soarez's (1524-93) textbook De arte rhetorica, in which he reiterates Cicero's claim that eloquence has dignity, because it has "always flourished and held sway" among "free people."27

Soarez, a Portuguese Jesuit and teacher of rhetoric in the colleges of Lisbon and Coimbra, was commissioned by his superiors to write De arte rhetorica for the use of the Jesuit colleges. The first edition of the textbook was printed in 1562 and a second and stylistically emended version was published in $1565 .{ }^{28}$ Soarez's book is essentially a compendium of classical rhetoric, gleaned from the writings of Cicero, Aristotle (384-22 BC), and Quintilian (35-100). It has been calculated that in his book Soarez quotes Aristotle twenty-two times, Quintilian 119 times, and Cicero, 410 times. ${ }^{29}$ The book was reprinted seventyeight times between 1562 and 1620 and was, in the words of Peter Mack, "the

26 Ratio atque institutio studiorum, 119: "Stylus [...] ex uno fere Cicerone sumendus est: \& omnes quidem ejus libri ad stylum aptissimi."

27 Cipriano Soarez, De arte rhetorica libri tres ex Aristotele, Cicerone, \& Quintiliano praecipue deprompti (Paris: Apud Thomam Brumennium 1576), 1: "Dignitas eloquentiae, vel ex eo intelligi potest, quod in omni libero populo, maximeque in pacatis, tranquillisque civitatibus praecipue semper floruit, semperque domina est."

Jean Dietz Moss and William A. Wallace, Rhetoric and Dialectic in the Time of Galileo (Washington, DC: The Catholic University of America Press, 2003), 115-16.

29 Maryks, Saint Cicero and the Jesuits, 91. 
most successful rhetoric textbook of the second half of the sixteenth century and the most published textbook of rhetoric published in southern Europe during the Renaissance." ${ }^{30}$ Brian Vickers in turn has estimated that by 1599, when the Jesuits ran 245 schools and had approximately ten thousand members - many of whom worked as teachers- "something like a quarter of a million students across Europe and South America were exposed to Soarez' manual each year."31

The civic values embedded in classical rhetoric and manifested in Soarez's textbook were further communicated through a daily study of classical authors. The Jesuit secondary education consisted of a five-year program, which was divided into three grammar classes—basic, medium, and advanced—and the classes of the humanities and rhetoric. Besides textbooks such as Aelius Donatus's (320-80) Ars minor and Johannes Despauterius's (1480-1520) De generibus nominum, the students of grammar at the Jesuit college of Messina (the first proper Jesuit college, established in 1548) started with Cicero's Epistulae ad familiares, Virgil's Eclogues, and Terence, and, in the advanced grammar class, continued with Cicero's letters "or De amicitia or De senectute" and variably with Sallust or Terence. ${ }^{32}$ From the very beginning of their studies, then, the students were exposed to Cicero's moral philosophy and Sallust's histories. These were texts, which were used to introduce the students to both eloquent Latin and ancient, civically oriented wisdom.

While the main emphasis of the grammar classes was on learning Latin and, when possible, Greek, the aim of the humanities class was to provide the students with a well-rounded learning in poetry, history, and moral philosophy. This was achieved through the study of Roman, Greek, and humanist authors. As Hannibal du Coudret (1525-99) specifies in 1550, the humanities class of the Jesuit college at Messina studied Erasmus's De copia verborum, Horace's Ars poetica, Cicero's Tusculanarum questionum liber primus, followed by Greek grammar and Aesop's (620-564 BC) fables, Aristophanes's (444-385 BC) Pluto, Erasmus's De conscribendis epistolis, Cicero's Epistulae ad familiares, a careful selection of Martial's epigrams and three books from Caesar's Commentarii

30 Peter Mack, A History of Renaissance Rhetoric, 1380-1620 (Oxford: Oxford University Press, 2013), 177, 179 .

31 Brian Vickers, "Some Reflections on the Rhetoric Textbook," in Renaissance Rhetoric, ed. Peter Mack (Basingstoke: The Macmillan Press Ltd, 1994), 86.

32 Lukács, Monumenta paedagogica, 1:97-98: "una lettione delle epistole di Tullio o Terentio o egloge de Virgilio [...] nella ultima scuola di grammatica si lege [...] l'epistole di Tullio familiare, o l'Amicitia, o De senectute; o Salustio [...] o anchora Terentio, come fu l'anno passato." 
de bello Gallico. The previous year, du Coudret notes, the humanities students had read Lorenzo Valla's De elegantia Latinae linguae, Sallust, Virgil, and Cicero's letters and De officiis. He then clarifies that currently-in 1551-the humanities class is reading Livius (59 BC-17 AD), Virgil, Homer's Iliad, Isocrates's speeches, Plautus's (255-185 вC) Amphitrione, Aristophanes's Ranae and Lucian's (125-180) dialogues alongside Greek grammar and syntax. The students of the rhetoric class started their morning with Cicero's De partitione oratoria and, alternately, either with Quintilian's Institutionum oratoriorum or Rhetorica ad Herennium. In the afternoon, they studied Cicero's speeches and (or) "some historian."33

Du Coudret's description of the Messina curriculum in $155^{1}$ evokes a number of observations. Firstly, the curriculum features writers whose reputation was considered questionable in the Catholic community. Besides having written in favor of the suspicious philosophy of Epicurus (341-270 BC), Valla exposed the inauthenticity of the Donatio Constantini (the document that for centuries was regarded as a proof for Constantine the Great's (r.306-37) donation of Rome to the pope) and no doubt earned himself notoriety among many supporters of the papal authority. Another problematic figure in the Messina curriculum was Erasmus, whose works were placed on the first Index librorum prohibitorum in 1559. Loyola expressed doubts about the Dutch humanist years before the publication of the 1559 list of prohibited books, but Nadal systematically defended the use of Erasmus's writings in Jesuit schools. Loyola allowed this to happen, although with some reservations: in 1553 he instructed the college of Messina only to use what is "good" in Erasmus (the same applied to Martial and Horace). ${ }^{34}$ In 1557, Laínez, Ignatius's successor as the superior general, informed the Jesuits at Ingolstadt and Padua that they were allowed to use Erasmus's writings in the classroom. ${ }^{35}$ Obviously, this became more difficult after the publication of the 1559 Index, but even then there is some evidence that Erasmus's texts continued to be read in Jesuit schools. ${ }^{36}$

Secondly, and related to the first observation, the Messina curriculum is void of Christian texts; it consists of pagan authors-including writers of comedies

33 Ibid., 1:100-2.

34 Agustí and Lecina, Sancti Ignatii de Loyola Societatis Jesu fundatoris, 5:421: "de Martiale et Horatio et simili si leva quello chè dishonesto [...] si fa etiam una copia più breve in versi, dove si contiene ii buono di Erasmo." For Nadal's defense of Erasmus, see Aldo Scaglione, The Liberal Arts and the Jesuit College System (Amsterdam: John Benjamins Publishing Company, 1986), 78.

35 John O'Malley, Religious Culture in the Sixteenth Century: Preaching, Rhetoric, Spirituality, and Reform (Brookfield, vT: Variorum, 1993), 476.

36 Scaglione, Liberal Arts and the Jesuit College System, 78-79. 
and satires - and humanists of unorthodox reputation. This aspect of the curriculum emphasizes the civic (as opposed to explicitly religious) nature of the Jesuit secondary education. It should be remembered, however, that religion was integrated in the daily life of the students in the form of scheduled prayers, Masses, and other services.

Thirdly, in $155^{\circ}$, the teachers of rhetoric at Messina and elsewhere had to make do without the help of Soarez's textbook. These pedagogical challenges no doubt guided Soarez in his writing and encouraged him to furnish Cicero's and Quintilian's ideas-arguably less accessible in their original form—with a precise Aristotelian form and structure. Notwithstanding these questions, the Messina curriculum became the model for other Jesuit schools and its contents were largely confirmed in the 1599 Ratio studiorum.

Without doubt, Cicero was the key figure in the Jesuit secondary education. The importance of Cicero is reflected in the Ratio studiorum, according to which "knowledge of the language" can be acquired through "daily readings" of Cicero's works. In particular, students should read such works, which deal with "moral philosophy."37 The Jesuit pedagogues used Cicero's writings to impart linguistic and moral knowledge, an undertaking, which to a large extent responded to the requirements Cicero himself had imposed on rhetoric. In his view, "wisdom without eloquence" was of little civic use, while "eloquence without wisdom" was "highly disadvantageous" and "never helpful." 38 The same idea of the inseparability of eloquence and reason is reiterated in Soarez's forewords to his De arte rhetorica: "oratory is almost like the image of reason."39

\section{Virtue in Action}

If the aim of the Jesuit secondary education was to instruct students in language(s) and moral wisdom, as I believe it was, it follows that the aim of such an education was to produce virtuous, active citizens. It was not enough

37 Ratio atque institutio studiorum, 128-29: "Ad cognitionem linguae, quae in proprietate maxime \& copia consistit, in quotidianis praelectionibus explicetur ex Oratoribus unus Cicero iis fere libris, qui philosophiam de moribus continent."

38 Cicero, De inventione, Loeb Classical Library (Cambridge, MA: Harvard University Press, 1949), 2: "sapientiam sine eloquentia parum prodesse civitatibus, eloquentiam vero sine sapientia nimium obesse plerumque, prodesse numquam."

39 Soarez, De arte rhetorica, second proemium: "Est enim oratio quasi rationis imago quaedam." 
for the Jesuits to teach Latin grammar or syntax and it was equally insufficient to limit their educational objectives to the teaching of moral principles. For Cicero, Quintilian, and the Renaissance humanists, being eloquent was a crucial part of being a good citizen; and being a good orator was inseparable from being a good man. "Unless you are a good man," Quintilian asserts, "you will find it impossible to be a good orator."40

In the context of classical rhetoric and the studia humanitatis that were taught at Jesuit colleges, being a good man — a man of virtue or piety—was inseparable from civic values and the notion of the Ciceronian orator. Why would one learn eloquence and moral wisdom if not for social or civic purposes? This takes us back to the question of the common good expressed in the Jesuit Constitutions as one of the key concerns of the Society of Jesus. To save souls or to help others necessitated persuasion. Rhetoric, or the art of persuasion, was an indispensable skill of any Jesuit working as a preacher, teacher, confessor, or advisor. Needless to say, Jesuit preachers lived in a different time, place, and culture than Cicero, but so did the Renaissance humanists. While Cicero's was a pagan world, both the humanists and the Jesuits adjusted what they learned from the Roman orator to their Christian creed and values. The Jesuit education turned the classical orator into a citizen of respublica christiana, not necessarily into one who pursued a clerical career, but one who was instructed in eloquence and such wisdom, which gleaned from Christian and pagan traditions.

For Cicero, what is praiseworthy about virtue always "consists of action."41 In line with this observation, vita activa - active participation to civic lifebecame the foundational principle of Quattrocento humanists such as Bruni. Again, the Jesuits followed Cicero and the humanists: echoing Cicero, chapter 46 of Book I in Soarez's De arte rhetorica is titled "De virtute, quae in actione consistit." 42 Soarez specifies that "virtue that is in action," consists of "justice, fortitude, and temperance." These cardinal virtues-also discussed in Cicero's De officiis - formed the basic guidelines of behavior and civic life. Far from rejecting the Ciceronian or humanist call for action, the Jesuits transformed it into a spiritually inspired mode of engaging with their surroundings and with other people. Nadal referred to this approach when he described Loyola

40 I quote from Quentin Skinner, Reason and Rhetoric in the Philosophy of Thomas Hobbes (Cambridge: Cambridge University Press, 1996), 88.

41 Cicero, De officiis, Loeb Classical Library (Cambridge, MA: Harvard University Press, 1913), 20: "Virtutis enim laus omnis in actione consistit."

42 Soarez, De arte rhetorica, $3^{8}-39$ : "virtus, quae in actione posita est, tres habet partes, iustitiam, fortitudinem, \& temperantiam." 
as someone who was "contemplative while in action" and saw God "in all things." ${ }^{43}$ Nadal's remark implies an attitude, which was informed by keen awareness both of the self and the other. One manifestation of such an attitude was the famous Jesuit adaptability (accommodatio), which, despite its beneficial impact on social interaction, gained the Jesuit order many enemies who, like the French Jansenists, claimed that the Jesuits lacked moral fiber. ${ }^{44}$

The Jesuit commitment to the principle of accommodation, however, brings us back to classical rhetoric. A speech delivered with no regard whatsoever to the needs, expectations, and the character of the audience would have been considered a highly unusual performance by any ancient orator. On the contrary, as Cicero advises us, it is a basic requirement of any orator that he uses a "style" that is "accommodated to the minds and general sensibilities of mankind." 45 Furthermore, Cicero writes that "in oratory the very cardinal sin is to depart from the language of everyday life" and from "the usage approved by the sense of the community."46 Admittedly, Cicero was a lawyer and concerned with judicial rhetoric, while the Jesuits employed Christian or sacred oratory (or, if we want to think in terms of classical rhetoric, they preferred epideictic and deliberative for judicial rhetoric). It is nevertheless evident that the Jesuits were highly concerned about and aware of the specific characteristics of their audience. For example, the Italian Jesuit diplomat Antonio Possevino (1533-1611) underlined the importance of learning different styles of letter writing, because one had to distinguish between republican, monarchic, and ecclesiastical audiences and accommodate one's style accordingly. ${ }^{47}$ In his De arte rhetorica, Soarez in turn observes that when addressing a "republic," the orator should have knowledge of "the mores of the community." Because

43 I quote from John W. O'Malley, "Early Jesuit Spirituality: Spain and Italy," in O'Malley, Saints or Devils Incarnate?: Studies in Jesuit History (Leiden: Brill, 2013), 121-45, here 126: "simul in actione contemplativus."

44 Maryks, Saint Cicero and the Jesuits, 127-34.

45 Cicero, De oratore, Loeb Classical Library, (Cambridge, MA: Harvard University Press, 1942), 40: "Hoc enim est proprium oratoris [...] oratio [...] hominum sensibus ac mentibus accommodate." Here the Loeb translation ignores the key term "accommodated," which is why I prefer Quentin Skinner's translation in Skinner, Reason and Rhetoric, 117.

46 Cicero, De oratore, 10: "vitium vel maximum sit a vulgari genere orationis, atque a consuetudine communis sensus abhorrere."

47 Antonio Possevino, Cicero, collatus cum ethnicis, \& sacris scriptoribus: Ad bibliothecam selectam auctoris pertinens (Rome: Apud Paulum Meietum 1593), 13: "Dubium autem non est, aliam scribendi epistolas rationem esse apud Respublicas, aliam apud alios Principes, aut Monarchas; aliam item apud eos, qui clavum Ecclesiae tenant." 
these "change often," Soarez concludes, also "the style of the speech needs to be changed frequently."48

The accommodation of speech to "the minds and general sensibilities" of the audience served the purpose of persuasion. Before the orator can succeed in persuading the audience, he or she should make sure that the speech is intelligible to those who listen, and that it evokes the audience's goodwill towards the speaker. Both of these points are possible only if the orator knows his or her audience. Delivering a speech according to the principles of classical rhetoric thus involves both the speaker and the audience. This means that such speech is dialogic and inclusive (rather than exclusive), and, as such, an act in line with the values of civic humanism.

\section{Conclusion}

Neither Cicero, nor the Renaissance humanists could conceive of scientia civilis that was not based on the art of rhetoric. ${ }^{49}$ While in general the Jesuits were not particularly interested in analyzing political science, they nonetheless adopted and taught Ciceronian rhetoric, which, as discussed above, was inseparable from civic aspirations and practices. ${ }^{50}$ To emphasize the specific characteristics of Renaissance rhetoric and the significance of the Jesuits' adoption of Ciceronian and humanist rhetoric it is worth noting that rhetoric has not always been regarded as the foundation of civic life or scientia civilis. It has been observed that to medieval theorists rhetoric was almost exclusively an

48 Soarez, De arte rhetorica, 49: "Ad consilium de Repub. dandum, caput est nosse Remp. ad dicendum vero probabiliter nosse mores civitatis, qui quia crebro mutantur, gens quoque orationis est saepe mutandum."

49 Skinner, Reason and Rhetoric, 2.

5o There were, however, Jesuits who participated in contemporary political debates. For example, Pedro de Ribadeneyra's Tratado de la religión y virtudes que deve tener el Principe Christiano, para governar y conservar sus Estados (Madrid: P. Madrigal, 1595) contributed to the anti-Machiavellian discourse; Juan de Mariana's De rege et regis institutione libri III (Toledo: Apud Petrum Rodericum, 1599) advocated tyrannicide; and Robert Bellarmine wrote extensively about the nature of papal power in his Tractatus de potestate summi pontificis in rebus temporalibus adversus Gulielmum Barclaium (Cologne: Sumptibus Bernardi Gualtheri, 1611). For further reading, see Harro Höpfl,Jesuit Political Thought: The Society of Jesus and the State, c. 1540-1630 (Cambridge: Cambridge University Press, 2004); Harald E. Braun, Juan de Mariana and Early Modern Spanish Political Thought (Farnham: Ashgate, 2007); Stefania Tutino, Empire of Souls: Robert Bellarmine and the Christian Commonwealth (Oxford: Oxford University Press, 2010). 
"art of ornamentation" and that from the seventeenth century onwards rhetoric turned into "a mechanistic catalogue of elocutionary devices and verbal techniques. ${ }^{n 1}$ However, when the Jesuits constructed their educational system in the sixteenth century, rhetoric was-due to the humanists' obsession with the classical antiquity - once again considered an essentially civic discipline. Pierre Fabri (1450-1535), one of the many sixteenth-century authors of rhetoric manuals, explicitly asserted that "rhetoric is political science." 52

The Renaissance humanists' concept of rhetoric as scientia civilis emphasized qualities such as flexibility and openness. Rhetoric was understood as debate that advanced the common good; for someone like Valla, it has been suggested, rhetoric stood for critical inquiry, which consisted of such discursive exchange that could engender true propositions. ${ }^{53}$ Renaissance rhetoric questioned rigid dogmatism and closed, circular reasoning. Above all, it questioned attempts to curb dialogue.

That the Jesuit secondary education was established under the auspices of Renaissance humanism is manifested not only in the curricula of the Jesuit colleges, but also in the Jesuit appreciation of adaptability and accommodatio. These two characteristics of the Society of Jesus - the humanist curriculum and the principle of accommodatio - facilitated effective communication. The emphasis that the Jesuits put on communication bespeaks their concern for the common good. This also was a key concern of the civic humanists whose general agenda was marked by the values of classical republicanism. While to a large extent following Cicero and the Renaissance humanists, the Jesuits substituted the framework of classical republicanism with that of respublica christiana. In contrast to the medieval notion of contemptus mundi, they aspired toward a Christian commonwealth administered by human agency and dependent on the well-rounded education of the youth. The Jesuits' adoption of the Aristotelian-Thomist view of man as a civic being was compatible with the key assumptions of the Renaissance civic humanism. Not satisfied with a merely academic subscription to the concept of zoon politikon (political animal), the

$51 \quad$ William J. Kennedy, Rhetorical Norms in Renaissance Literature (New Haven: Yale University Press, 1978), 7, 13 .

52 I quote from Peter Mack, A History of Renaissance Rhetoric, 286n15: "Rhétorique donc est science politique." The same point was made by Cicero, De inventione, 14: "oratoriam facultatem in eo genere ponemus, ut eam civilis scientiae partem esse dicamus" [we will classify oratorical ability as a part of political science].

53 Nancy Struever, "Lorenzo Valla: Humanist Rhetoric and the Critique of the Classical Languages of Morality," in Renaissance Eloquence, ed. J. J. Murphy (Berkeley: University of California Press, 1983), 195. 
Jesuits quickly established themselves as significant figures in their own civic communities. This was particularly true with regard to their role as educators.

While Christian piety played an important role also in the moral outlook of the humanist pedagogues, the promotion of piety and Christian virtues was the bedrock of Jesuit education. The rapid spread of Jesuit schools across Europe and the rest of the world indicates the efficiency with which the Jesuits advanced Christian piety and civic values: by the death of Loyola in 1556 (sixteen years after the founding of the Jesuit order) there were forty Jesuit schools in Europe and India, and by 1615 the number of Jesuit schools was 372 worldwide. ${ }^{54}$ Stretching their network also beyond Europe, the Jesuit colleges provided instruction in Christian doctrine and civic values from Lisbon to Goa, and from Lima to Vilnius. This - and the systematic coupling of Christian and civic virtues - testifies to the impact that Jesuit education had on the implementation of civic and administrative systems in the early modern period.

54 John W. Padberg, "Development of the Ratio studiorum," in The Jesuit Ratio studiorum: $400^{\text {th }}$ Anniversary Perspectives, ed. Vincent Duminuco (New York: Fordham University Press, 200o), 81; John Patrick Donnelly, S.J., "Planning Jesuit Education from Loyola to the 1599 Ratio studiorum," Sixteenth-Century Essays \& Studies 63 (2003): 57-69, here 59. 